\title{
Effect of Reduced Irrigation and Potassium Fertilization on Quantity and Quality of Giza 95 Cotton Plants
}

\author{
S.Sh. Abd El-Gayed ${ }^{(1) *}$ and S.O. Bashandy ${ }^{(2)}$ \\ ${ }^{(1)}$ Cotton Resarch Institute, Agricultural Research Center, Giza, Egypt; (2) Soil and \\ Water Science Department, Faculty of Agriculture, Minia University, Minia, Egypt.
}

\begin{abstract}
$\mathbf{T}$ WO FIELD experiments were conducted at the Farm of Sids Agricultural Research Station, ARC, Egypt, during 2016 and 2017 seasons to study the response of cotton to potassium fertilization $\left(12,24,36\right.$ and $\left.48 \mathrm{~kg} \mathrm{~K}_{2} \mathrm{O}\right)$ as soil application as well as $5 \mathrm{~kg} \mathrm{~K}_{2} \mathrm{O}$ / fad as foliar spraying three times at squaring, beginning of flowering and top of flowering) under different irrigation intervals at recommended irrigation interval (every 12 days), every 15 days, every 18 days and every 21 days). The results show that increasing potassium fertilization up to $36 \mathrm{~kg}$ or $48 \mathrm{~kg} \mathrm{~K} 2 \mathrm{O} /$ fad as soil application as well as decreasing irrigation interval to 12 days exhibited the highest values of plant height, number of fruiting branches/ plant, number of open polls/plant, seed cotton yield, earliness \% and seed index as well as leaf content of N, K, chlorophyll A and B and carotenoids. On the other hand, lint percentage and fiber properties did not respond to either potassium or irrigation treatments, while $\mathrm{P}$ content increased as increasing water irrigation. Increasing both potassium levels and the irrigation intervals improved water use efficiency and water utilization efficiency. The results of the interaction between potassium and irrigation treatments reveal that irrigation cotton plants every 15 days when fertilized with $48 \mathrm{~kg} \mathrm{~K}_{2} \mathrm{O} /$ fad as soil application produced highest growth, yield and its components and chemical content of cotton leaf equal to these irrigated every 12 days and supplied water 36 or $48 \mathrm{~kg} \mathrm{~K}_{2} \mathrm{O} /$ fad.
\end{abstract}

Keywords: Cotton, Irrigation intervals, Potassium, Growth, Yield and its components, Chemical leaf content and water relations.

\section{Introduction}

After soya, cotton seed is considered as the second oil seed in terms of oil production rate (Naseri, 1994). This product is called white gold due to its high commercial and economic value and with public awareness increase, the need for cotton textiles is rising. Numerous factors play a role in acquiring optimum yield of cotton plant among them water and nutrients. Therefore, irrigation and nutrient management are two very substantial and crucial issues in optimal production of cotton.

Potassium is one of major elements for crop growth and yield development, although it is not a integral component of any cellular organelle or structural part of plant. It is the most abundant cation in plants and is associated or involved with many physiological princesses supporting plant growth and development. Water relations, photosynthesis, assimilate transport and enzyme activation all can be impacted by potassium (Pettigrew, 2008). The response of cotton productivity to potassium application as soil application were reported by many authors such as Abd El-Aal et al. (2000), Abd El-Shafy et al. (2001), Kassem \& Ahmed (2005), Sawar et al. (2012), Gebaly (2012) and Abd El-Gayed \& Awadalla (2014). Also, potassium fertilizer can be applied directly to the aerial portion of plants. It must be penetrating the cuticle of the leaf or the stomata and they enter the cells. This method provides more rapid utilization of potassium and permits the correction of potassium deficiencies in less time then would be required by soil application (Tisdale, 1997). Ghourab et al. (2000), Gebaly (2012) and Abd El-Gayed \& Awadalla (2014), reported that added potassium as foliar spraying improved growth, yield and its components of cotton plant.

Water stress is one of main problems in arid and semi arid regions. Lack of water effect most plant physiological processes, e. g., photosynthesis,

"Corresponding author email: gmohamed78@yahoo.com DOI: 10.21608/agro.2018.5683.1122

C2018 National Information and Documentation Center (NIDOC) 
photosynthetic material transmission to seeds, cellular development, coalescence and transmission of nutrients in plant (Davis et al., 2007). Drought influenced plant height caused by hormonal imbalance (cytokinin, abscisic acid) that affected growth due to changes in cell wall extensibility (Zhao et al., 2006). Ouda et al. (2010) reported that up to $20 \%$ of full irrigation could be saved with yield reduction reached to $7 \%$. Although cotton is known as an adaptable plant, the different amounts of irrigation water have a significant affect on cotton growth (Onder et al., 2009). Geerts \& Raes (2009) indicated the deficit irrigation water in various products leads to enhancing the water use efficiency without having to drastically reduce yield. Since drought tolerance in plants varies with cultivar and phonological stages, deficit irrigation needs careful study of plant response to drought stress. Water stress quickly reduces plant growth, height and cotton leaf area and result in the reduction of lint yield (Siskani et al., 2015). Burke \& Omahony (2001) pointed out that sever water stress in the early growth period to mid flowering stage causes slower growth, plant shrinkage, less nodes and prolific branches and less leaf area index. Akbari (2011) mentioned that the highest cotton yield was referred to irrigation cotton plant with $75 \%$ from water requirement. Whereas, Fathi et al. (2011) found that $66 \%$ from water requirement of cotton gave the highest cotton yield.

The agricultural sector consumes almost 80$90 \%$ of the total water allocated to Egypt, however the increase of population is normally resulted in steady decrease in per capita share of water (Ewis et al., 2015). Efficient irrigation methods could mitigate the problem of insufficient water resources.

The objective of this study was to investigate how to reduce the water irrigation requirement of cotton by using potassium fertilizer and its effect on cotton growth, yield and yield compounds and leaf content as well as water use efficiency.

\section{Materials and Methods}

Two field experiments were conducted at the Farm of Sids Agricultural Research Station, ARC, Beni-Suef Governorate, Egypt during 2016 and 2017 seasons to investigate the effect of potassium fertilization levels, i. e., 12, 24, 36 and $48 \mathrm{~kg} \mathrm{~K}_{2} \mathrm{O} /$ fad as soil application and foliar spraying of $5 \mathrm{~kg} \mathrm{~K}_{2} \mathrm{O} /$ fad three limes at squaring, begging of flowering and top of flowering under different irrigation intervals (at recommended irrigation intervals (every 12 days, every 15 days, every 18 days and every 21 days) on growth, yield and its components, fiber quality and leaf chemical contents as well as water relations. Some physical and chemical properties of the experimental sites were determined according to Klute (1986) and Page et al. (1982), respectively and listed in Tables 1 and 2.

The experiment was laid out in split plot in complete randomized block design in four replicates, where irrigation treatments were located in the main plots, while potassium treatments were involved in sub plots. The experimental plot was $12 \mathrm{~m}^{2}(4.0 \mathrm{~m} \times 3.0 \mathrm{~m})$ including five ridges. Each ridge was $4.0 \mathrm{~m}$ long, $0.6 \mathrm{~m}$ wide with hills of $0.2 \mathrm{~m}$ apart in one side of the ridge. Cotton seeds, variety Giza 95 obtained from Cotton Research Institute were sown on 7 and 9 April in the two seasons, respectively. Hills were thinned after three weeks from planting to two plants. All plants fertilized with $22 \mathrm{~kg} \mathrm{P}_{2} \mathrm{O}_{5} /$ fad as superphosphate $(15.5 \%)$ before planting. Also, all plots received $60 \mathrm{~kg} \mathrm{~N} /$ fad as ammonium nitrate $(33.5 \% \mathrm{~N})$ in two equal doses after thinning and 15 days later.

TABLE 1. Some physical and chemical properties of the experimental soil before planting.

\begin{tabular}{lcc}
\hline Soil properties & $\mathbf{2 0 1 6}$ & $\mathbf{2 0 1 7}$ \\
\hline Physical properties: & & \\
Particle size distribution: & & \\
Clay (\%) & 55.14 & 56.26 \\
Silt (\%) & 28.27 & 26.71 \\
Sand (\%) & 16.59 & 17.03 \\
Texture grade & Clay & Clay \\
Chemical properties: & & \\
pH (1:2.5 soil-water & & \\
suspension) & 8.21 & 8.05 \\
EC, soil paste (dS m & & \\
Organic matter $(\%)$ & 1.12 & 1.18 \\
Available N (ugg $\left.{ }^{-1}\right)$ & 1.72 & 1.79 \\
Available P (ugg- $\left.{ }^{-1}\right)$ & 22.14 & 21.16 \\
Available K (ugg & 14.80 & 15.20 \\
\hline
\end{tabular}


TABLE 2. Some soil water constants for the experimental soil.

\begin{tabular}{lccccc}
\hline Season & $\begin{array}{c}\text { Soil depth } \\
(\mathbf{c m})\end{array}$ & $\begin{array}{c}\text { Field capacity } \\
\mathbf{( \% )}\end{array}$ & $\begin{array}{c}\text { Wilting point } \\
\mathbf{( \% )}\end{array}$ & $\begin{array}{c}\text { Bulk density } \\
\left(\mathbf{g ~ c m}^{-3}\right)\end{array}$ & $\begin{array}{c}\text { Available } \\
\text { water }(\%)\end{array}$ \\
\hline \multirow{2}{*}{2016} & $0.0-15$ & 45.0 & 21.4 & 1.13 & 23.6 \\
& $15-30$ & 37.8 & 18.1 & 1.26 & 19.7 \\
& $30-45$ & 35.8 & 17.5 & 1.29 & 18.3 \\
2017 & $45-60$ & 33.2 & 16.1 & 1.33 & 17.1 \\
\hline & $0.0-15$ & 46.3 & 22.2 & 1.17 & 24.1 \\
& $15-30$ & 37.3 & 17.7 & 1.30 & 19.6 \\
& $30-45$ & 35.6 & 16.8 & 1.36 & 18.8 \\
\hline
\end{tabular}

\section{The irrigation treatments}

- Sowing irrigation for all plots.

- First irrigation: For all plots after 21 days from sowing.

- Second irrigation: After 36 days from sowing and after added the first nitrogen fertilizer dose for all plots.

- Third irrigation: After 51 days from sowing and after added the second nitrogen fertilizer for all plots + the treatments of soil potassium application.

- Then the following irrigation done as the interval treatments, i. e., 12, 15, 18 and 21 days which means added 6, 5, 4 and 3 irrigation, respectively.

At harvest ten guarded plants were randomly taken from the central row of each plot to determine the following parameters. Plant height $(\mathrm{cm})$, number of fruiting branches/plant, number of open bolls/plant, boll weight $(\mathrm{g})$, seed cotton yield (kentar $/ \mathrm{fad}$, kentar $=157.5 \mathrm{~kg}$. $)$, earless (\%), weight of 100 seeds (g), lint (\%) micronaire reading and pressely index. Also, a representative samples of cotton leaves from each plot were taken randomly from the top fourth node leaves at 15 days after full flowering stage for 2017 season only to determine N, P and $\mathrm{K}$ concentration in leaves according to Chapman \& Pratt (1961) as well as determine chlorophyll A and chlorophyll B according to Arnon (1949) and carotenoids according to Rolbelen (1957).

\section{Crop - water relationship}

Seasonal consumptive use (CU)

To determining the crop water consumptive use, soil samples were taken just before and after $48 \mathrm{~h}$ for each irrigation, as well as at harvest time in $15 \mathrm{~cm}$ increment system to $60 \mathrm{~cm}$ depth of the soil profile. The crop water consumptive use between each two successive irrigations was calculated according to Israelsen \& Hansen (1962) as follow:

$$
\mathrm{Cu}=\frac{\mathrm{D} \cdot \mathrm{Bd}(\mathrm{Q}-\mathrm{Q} 1)}{100}
$$

where: $\mathrm{Cu}=$ Actual consumptive use $(\mathrm{cm}), \mathrm{D}=$ Effective root zone depth $(\mathrm{cm}), 60 \mathrm{~cm}, \mathrm{Bd}=$ Bulk density of depth $\left(\mathrm{g} / \mathrm{cm}^{-3}\right), \mathrm{Q} 1=$ Soil moisture percentage (wt/wt) two days after irrigation and Q2= Soil moisture percentage (wt/wt) just before the next irrigation.

Water use efficiency (WUE)

The water use efficiency as kg seed cotton/ $\mathrm{m}^{3}$ water consumed was calculated for each treatment as the formula described by Vites (1965).

$$
\text { WUE }\left(\mathrm{kg} / \mathrm{m}^{3}\right)=\frac{\text { Cotton yield }(\mathrm{kg} / \mathrm{fad})}{\text { Consumptive use }\left(\mathrm{m}^{3} / \mathrm{fad}\right)}
$$

\section{Water productivity (WP)}

Water productivity is an efficiency term calculated as a ratio of product water output over water input. Water productivity in the present study is expressed as kilogram of seed cotton obtained per the unit of applied irrigation water (FAO, 2003).

$$
\mathrm{WP}=\left(\mathrm{kg} / \mathrm{m}^{3}\right)=\frac{\text { Seed cotton yield }(\mathrm{kg} / \mathrm{fad})}{\text { Water applied }\left(\mathrm{m}^{3} / \mathrm{fad}\right)}
$$


Submerged flow orifice with fixed dimension was used to measure the amount of water applied according to the following equation (Michael, 1978):

\section{$\mathrm{Q}=\mathrm{CA} \sqrt{ } 2 \mathrm{gh}$}

where: $\mathrm{Q}=$ Discharge through orifice $(\mathrm{L} / \mathrm{sec}), \mathrm{C}=$ Coefficient of the discharge (0.61), $\mathrm{A}=$ Crosssection area of orifice $\left(\mathrm{cm}^{2}\right), \mathrm{G}=$ Acceleration of gravity $\left(981 \mathrm{~cm} / \mathrm{sec}^{2}\right)$ and $\mathrm{H}=$ Pressure head causing discharge through the orifice $(\mathrm{cm})$.

The time needs for each plot was recorded. The obtained data were subjected to proper analysis according to methods of Snedecor \& Cochran (1980). The least significant differences (L.S.D.) at significance of 0.05 level was used to verify the significance of differences between treatments.

\section{$\underline{\text { Results and Discussion }}$}

\section{Growth parameters}

Data in Table 3 represent the effect of potassium fertilization and irrigation intervals and their interaction on cotton growth. The results clearly show that regardless irrigation treatments, potassium fertilization had a positive effect on both plant height and number of fruiting branches. Increasing potassium level up to $48 \mathrm{~kg}$ $\mathrm{K}_{2} \mathrm{O}$ /fad was significantly increased plant height and number of fruiting branches/plant. It is obvious that the differences between the effect of 36 and $48 \mathrm{~kg} \mathrm{~K}_{2} \mathrm{O} /$ fad were not reached to the significant values in both seasons. Added 36 or $48 \mathrm{~kg} \mathrm{~K} 2 \mathrm{O} /$ fad increased cotton plant height and number of fruiting branches/plant by about 4.5 and $4.9 \%$ for plant height, and 3.3 and $3.3 \%$ for number of fruiting branches/plant, respectively in the first season. Same trends were obtained in the second season. The data clearly indicate that spraying $5 \mathrm{~kg} \mathrm{~K}_{2} \mathrm{O} /$ fad three time on cotton leaves had somewhat similar effect as $24 \mathrm{~kg} \mathrm{~K}_{2} \mathrm{O} /$ fad as soil application. In this concern, Cope (1981) mentioned that the low use of K fertilizer in cotton may have serious consequences, as it appears to be more sensitive to $\mathrm{K}$ deficiencies than many other row crops, as the root system of cotton is less dense than of that of other crops. The effect of potassium on cotton growth is mainly due to its vital role in regulating of many physiological processes (potassium regulates the opening pand closing of stomata, and therefore regulates $\mathrm{CO}_{2}$ uptake). Potassium performs a number of functions (Tisdale et al., 1997). Similar results were obtained by Abd ElAal et al. (2000) and Abd El-Gayed \& Awadalla (2014).

As for irrigation treatments, the data indicate that increasing the irrigation intervals decreased both plant height and number of fruiting branches/plant. The highest mean values due to irrigation treatments were recorded for cotton plants received the highest amounts of water (irrigation every 12 days). The reduction in cotton growth caused by increasing the irrigation intervals is mainly due to limiting the plant ability to absorb nutrients needed for optimal growth and development of plant. Also, it is well recognized that water is not only required for different biochemical activities of all cells, but also awakes generated turgor pressure a driving force of cell (Xiong \& Zhu, 2002). Therefore, water deficit disturbs normal cellular activities and restricts plant growth. These results agree with those obtained by Ashry et al. (2012), Hamoda et al. (2014), Khalifa (2014) and Hafiz \& Ewis (2015).

With regard to the interaction between potassium fertilization and irrigation intervals, the result show that cotton growth was significantly affected by the interaction between the two factors. It is obvious to notice that the reduction in cotton plant height and numbers of fruiting branches due to increasing irrigation intervals was decreased by increasing potassium levels. The highest values of plant height or number of fruiting branches were obtained for cotton plants watered every 12 days or every 18 days under 36 or $48 \mathrm{~kg} \mathrm{~K} \mathrm{O} / \mathrm{fad}$. On the other hand, the plants irrigated every 21 days and received $12 \mathrm{~kg} \mathrm{~K}_{2} \mathrm{O} /$ fad showed the lowest cotton growth. In this concern, Brag (1972) pointed out that the lower water loss of plants well supplied with $\mathrm{K}$ was due to a reduction in transpiration rate, which not only depends on the osmotic potential of the mesophyll cells, but also to its controlled to large extent by the opening and closing of stomata. Similar result were obtained by Farrag et al. (2015) and Hafiz \& Ewis (2015).

\section{Yield components}

The data in Table 3 show the effect of potassium and irrigation treatments and their interactions on yield components of cotton, 
namely, number of open bolls/plant and boll weight. Concerning the main effect of potassium, the results reveal that increasing potassium level up to $48 \mathrm{~kg} \mathrm{~K}_{2} \mathrm{O} / \mathrm{fad}$ as soil application was significantly improved number of open bolls/ plant and boll weight in both seasons. It is obvious to notice that foliar spraying of $5 \mathrm{~kg} \mathrm{~K}_{2} \mathrm{O} / \mathrm{fad}$ had equal effect on cotton yield components as the effect of $24 \mathrm{~kg} \mathrm{~K} 2 \mathrm{O} / \mathrm{fad}$ as soil application. The positive effect of potassium on yield components is mainly due to its effect on growth parameters as mentioned before, where produced height plant and more fruiting branches/plant resulted in more flowers and bolls. In this connection, Mengel \& Kirkby (1987) mentioned that favorable potassium fertilization enhanced formation of carbohydrates, proteins, photosynthesis translocation regulation, and enzyme action, synthesis of nucleic acids, chlorophyll oxidative, and photo-phosphorylation of solution. These results are in line with those obtained by Akhtar et al. (2003) and Abd El-Gayed \& Awadalla (2014).

With regard to the main effect of irrigation treatments, the results clearly show that increasing the intervals between irrigation had a negative effect on yield components of cotton plants. The highest values of number of open bolls/plant and boll weight (22.7 and 3.04g in the first season and 22.5 and $3.05 \mathrm{~g}$ for the second one) were obtained when cotton plants watered every 12 days. In this connection, Siskani et al. (2015) reported that, the formation and growth of bolls is depended on the continued availability of assimilates. Any stress which reduces the availability of assimilates causes the reduction of number and weight of bolls by increasing their abortions. In severe water stress conditions, loss of flowers and bolls results in the reduction of number of bolls. Similar results were obtained by Hassan et al. (2016).

As for the interaction between potassium and irrigation treatments, the data show that both number of bolls/plant and boll weight were significantly affected by the interaction between the two studied factors. Increasing potassium level reduced the negative affect of increasing the intervals between irrigation. The treatment of $48 \mathrm{~kg} \mathrm{~K} \mathrm{~K}_{2} \mathrm{O} /$ fad under irrigation every 18 days gave number of open bolls/plant and boll weight significantly equal to those under watered every 12 days. On the other hand, the treatment of $12 \mathrm{~kg}$
$\mathrm{K}_{2} \mathrm{O}$ /fad under irrigation every 21 days exhibited the lowest cotton yield components. This may be due to potassium play important role in osmotic mechanisms and stomata conductance that important for plant water relationships (Pettigrew, 2008). These results agree with many workers such as Hassan et al. (2016).

\section{Seed cotton yield}

Data in Table 3 represent cotton seed yield as affected by irrigation intervals and potassium fertilization and their interaction. As for the main affect of potassium treatments, the results show that increasing potassium level was associated with significant increasing in seed cotton yield. The highest seed cotton yield (11.01 and $10.81 \mathrm{kentar} / \mathrm{fad}$ in the two seasons, respectively) were recorded under $48 \mathrm{~kg} \mathrm{~K}_{2} \mathrm{O} /$ fad as soil application, while $12 \mathrm{~kg} \mathrm{~K}_{2} \mathrm{O} /$ fad exhibited the lowest seed cotton yield in both seasons (10.11 and 9.94kentar/fad, respectively). The data also reveal that sprayed $5 \mathrm{~kg} \mathrm{~K}_{2} \mathrm{O} /$ fad on cotton plants produced somewhat seed cotton yield equal to those under $24 \mathrm{~kg} \mathrm{~K}_{2} \mathrm{O} /$ fad. The relative increasing in seed cotton yield caused by $48 \mathrm{~kg} \mathrm{~K}_{2} \mathrm{O} /$ fad over $12 \mathrm{~kg} \mathrm{~K}_{2} \mathrm{O} /$ fad reached to 8.9 and $9.0 \%$ in the two seasons, respectively. This is explained by potassium consider one of the important nutrient that own effect direct or indirect in vegetative and reproductive growth which reflected positively in seed cotton yield directly. Also, potassium application increased cotton root growth, consequently improved seed cotton yield (Chen \& Gabelman, 2000 and Rosolem, 2000). These results are similar to those obtained by Reddy (2000) and Akhtar (2003).

Considering the irrigation treatments, the data indicate that, under water stress conditions, seed cotton yield decreased was considerably. Seed yield in $100 \%$ water requirement treatment (every 12 days) produced $11.2,5.5$ and $3.9 \%$ increases compared with watered every 21,18 and 15 days in the first season, respectively. In this concern, Imam (2004) stated that water stress decreased seed cotton yield by reducing green leaf area duration in the final stages of development and can induces a sever reduction in production of assimilates by photosynthetic organs. These results agree with those obtained by Dagdelen et al. (2006) and Siskani et al. (2015). 
TABLE 3. Effect of irrigation intervals under potassium fertilization on some growth, yield and its components of cotton.

\begin{tabular}{|c|c|c|c|c|c|c|c|c|c|c|c|}
\hline \multirow{2}{*}{$\begin{array}{l}\text { Irrigation } \\
\text { intervals } \\
\text { (A) }\end{array}$} & \multirow{2}{*}{$\begin{array}{c}\text { Potassium } \\
\text { fertilization (B) }\end{array}$} & \multicolumn{2}{|c|}{$\begin{array}{l}\text { Plant height } \\
\text { (cm) }\end{array}$} & \multicolumn{2}{|c|}{$\begin{array}{l}\text { No. of fruiting } \\
\text { branches/plant }\end{array}$} & \multicolumn{2}{|c|}{$\begin{array}{l}\text { No. of open } \\
\text { bolls/plant }\end{array}$} & \multicolumn{2}{|c|}{$\begin{array}{l}\text { Boll weight } \\
\text { (g) }\end{array}$} & \multicolumn{2}{|c|}{$\begin{array}{l}\text { Seed cotton yield } \\
\text { (kentar/fad) }\end{array}$} \\
\hline & & 2016 & 2017 & 2016 & 2017 & 2016 & 2017 & 2016 & 2017 & 2016 & 2017 \\
\hline \multirow{5}{*}{$\begin{array}{l}\text { Every } 12 \\
\text { days }\end{array}$} & $12 \mathrm{~kg} \mathrm{~K}_{2} \mathrm{O} / \mathrm{fad}$ & 126.7 & 126.0 & 15.5 & 14.6 & 22.2 & 22.0 & 2.97 & 2.99 & 10.84 & 10.77 \\
\hline & $24 \mathrm{~kg} \mathrm{~K}_{2} \mathrm{O} / \mathrm{fad}$ & 130.2 & 129.2 & 15.6 & 14.8 & 22.7 & 22.6 & 3.04 & 3.05 & 11.04 & 10.90 \\
\hline & $36 \mathrm{~kg} \mathrm{~K}_{2} \mathrm{O} / \mathrm{fad}$ & 131.8 & 130.5 & 15.8 & 15.1 & 22.8 & 22.5 & 3.08 & 3.08 & 11.22 & 11.01 \\
\hline & $48 \mathrm{~kg} \mathrm{~K}_{2} \mathrm{O} / \mathrm{fad}$ & 131.8 & 130.5 & 15.9 & 15.2 & 22.9 & 22.7 & 3.09 & 3.08 & 11.24 & 11.15 \\
\hline & $5 \mathrm{~kg} \mathrm{~K}_{2} \mathrm{O} /$ fad (foliar) & 130.3 & 129.2 & 15.6 & 14.9 & 22.7 & 22.6 & 3.04 & 3.05 & 11.06 & 10.93 \\
\hline Mean & & 130.2 & 129.1 & 15.7 & 14.9 & 22.7 & 22.5 & 3.04 & 3.05 & 11.08 & 10.95 \\
\hline \multirow{5}{*}{$\begin{array}{l}\text { Every } 15 \\
\text { days }\end{array}$} & $12 \mathrm{~kg} \mathrm{~K}_{2} \mathrm{O} / \mathrm{fad}$ & 125.6 & 125.1 & 15.2 & 14.3 & 21.8 & 21.6 & 2.63 & 2.65 & 10.11 & 9.85 \\
\hline & $24 \mathrm{~kg} \mathrm{~K}_{2} \mathrm{O} / \mathrm{fad}$ & 129.2 & 128.3 & 15.4 & 14.6 & 22.1 & 22.0 & 2.68 & 2.69 & 10.62 & 10.24 \\
\hline & $36 \mathrm{~kg} \mathrm{~K}_{2} \mathrm{O} / \mathrm{fad}$ & 131.7 & 130.6 & 15.8 & 15.2 & 22.8 & 22.6 & 3.08 & 3.08 & 11.21 & 10.95 \\
\hline & $48 \mathrm{~kg} \mathrm{~K}_{2} \mathrm{O} / \mathrm{fad}$ & 131.7 & 130.5 & 15.8 & 15.2 & 22.8 & 22.7 & 3.09 & 3.09 & 11.22 & 10.98 \\
\hline & $5 \mathrm{~kg} \mathrm{~K}_{2} \mathrm{O} /$ fad (foliar) & 129.3 & 128.2 & 15.4 & 14.6 & 22.1 & 22.0 & 2.68 & 2.69 & 10.63 & 10.25 \\
\hline Mean & & 1129.5 & 128.5 & 15.5 & 14.8 & 22.3 & 22.2 & 2.83 & 2.84 & 10.76 & 10.45 \\
\hline \multirow{5}{*}{$\begin{array}{l}\text { Every } 18 \\
\text { days }\end{array}$} & $12 \mathrm{~kg} \mathrm{~K}_{2} \mathrm{O} / \mathrm{fad}$ & 125.0 & 124.6 & 15.1 & 14.1 & 21.2 & 21.0 & 2.52 & 2.53 & 9.83 & 9.67 \\
\hline & $24 \mathrm{~kg} \mathrm{~K}_{2} \mathrm{O} / \mathrm{fad}$ & 128.6 & 127.8 & 15.3 & 14.4 & 21.7 & 21.4 & 2.59 & 2.59 & 10.45 & 10.25 \\
\hline & $36 \mathrm{~kg} \mathrm{~K}_{2} \mathrm{O} / \mathrm{fad}$ & 130.7 & 130.2 & 15.6 & 15.0 & 22.2 & 22.0 & 2.87 & 2.90 & 11.03 & 10.93 \\
\hline & $48 \mathrm{~kg} \mathrm{~K}_{2} \mathrm{O} / \mathrm{fad}$ & 131.8 & 130.6 & 15.6 & 15.1 & 22.7 & 22.6 & 3.08 & 3.08 & 11.22 & 10.97 \\
\hline & $5 \mathrm{~kg} \mathrm{~K}_{2} \mathrm{O} /$ fad (foliar) & 128.6 & 127.8 & 15.3 & 14.5 & 21.7 & 21.4 & 2.58 & 2.59 & 10.45 & 10.26 \\
\hline Mean & & 128.9 & 128.2 & 15.4 & 14.6 & 21.9 & 21.7 & 2.73 & 2.74 & 10.60 & 10.42 \\
\hline \multirow{5}{*}{$\begin{array}{l}\text { Every } 21 \\
\text { days }\end{array}$} & $12 \mathrm{~kg} \mathrm{~K}_{2} \mathrm{O} / \mathrm{fad}$ & 124.6 & 124.1 & 15.0 & 14.0 & 20.7 & 20.5 & 2.45 & 2.46 & 9.65 & 9.47 \\
\hline & $24 \mathrm{~kg} \mathrm{~K}_{2} \mathrm{O} / \mathrm{fad}$ & 128.1 & 127.3 & 15.1 & 14.2 & 21.0 & 20.7 & 2.47 & 2.49 & 10.03 & 9.87 \\
\hline & $36 \mathrm{~kg} \mathrm{~K}_{2} \mathrm{O} / \mathrm{fad}$ & 130.2 & 129.8 & 15.3 & 14.8 & 21.5 & 21.2 & 2.55 & 2.56 & 10.17 & 10.03 \\
\hline & $48 \mathrm{~kg} \mathrm{~K}_{2} \mathrm{O} / \mathrm{fad}$ & 131.4 & 130.1 & 15.4 & 14.8 & 21.6 & 21.3 & 2.65 & 2.68 & 10.34 & 10.16 \\
\hline & $5 \mathrm{~kg} \mathrm{~K}_{2} \mathrm{O} /$ fad (foliar) & 128.1 & 127.3 & 15.1 & 14.2 & 21.0 & 20.6 & 2.48 & 2.50 & 10.05 & 9.88 \\
\hline Mean & & 128.5 & 127.7 & 15.2 & 14.4 & 21.2 & 20.9 & 2.52 & 2.54 & 10.05 & 9.88 \\
\hline \multirow{5}{*}{$\begin{array}{l}\text { Mean of } \\
\text { potassium } \\
\text { fertilization } \\
\text { (B) }\end{array}$} & $12 \mathrm{~kg} \mathrm{~K}_{2} \mathrm{O} / \mathrm{fad}$ & 125.5 & 125.0 & 15.2 & 14.3 & 21.5 & 21.3 & 2.64 & 2.66 & 10.11 & 9.94 \\
\hline & $24 \mathrm{~kg} \mathrm{~K}_{2} \mathrm{O} / \mathrm{fad}$ & 129.0 & 128.2 & 15.4 & 14.5 & 21.9 & 21.7 & 2.70 & 2.71 & 10.54 & 10.32 \\
\hline & $36 \mathrm{~kg} \mathrm{~K}_{2} \mathrm{O} / \mathrm{fad}$ & 131.1 & 130.3 & 15.6 & 15.0 & 22.3 & 22.1 & 2.90 & 2.91 & 10.91 & 10.73 \\
\hline & $48 \mathrm{~kg} \mathrm{~K}_{2} \mathrm{O} / \mathrm{fad}$ & 131.7 & 130.4 & 15.7 & 15.1 & 22.5 & 22.3 & 2.98 & 2.98 & 11.01 & 10.81 \\
\hline & $5 \mathrm{~kg} \mathrm{~K}_{2} \mathrm{O} /$ fad (foliar) & 129.1 & 128.1 & 15.4 & 14.6 & 21.9 & 21.7 & 2.70 & 2.71 & 10.55 & 10.33 \\
\hline \multicolumn{12}{|l|}{ L.S.D. at $5 \%$} \\
\hline & A & 0.63 & 0.60 & 0.12 & 0.11 & 0.13 & 0.13 & 0.08 & 0.07 & 0.10 & 0.09 \\
\hline & B & 0.87 & 0.81 & 0.14 & 0.13 & 0.15 & 0.14 & 0.08 & 0.07 & 0.11 & 0.10 \\
\hline & $\mathrm{AXB}$ & 0.90 & 0.89 & 0.17 & 0.16 & 0.17 & 0.17 & 0.10 & 0.09 & 0.13 & 0.12 \\
\hline
\end{tabular}


The results of analysis of variance indicate that the seed cotton yield was significantly affected by the interaction between potassium and irrigation treatments. Irrigation cotton plant every 15 days or 18 days when received the high dose of potassium ( $48 \mathrm{~kg} \mathrm{~K} \mathrm{~K}_{2} \mathrm{O} / \mathrm{fad}$ ) gave statistically seed cotton yield similar to those watered every 12 days and supplied with 36 or $48 \mathrm{~kg} \mathrm{~K} 2 \mathrm{O} /$ fad. This means that potassium fertilization reduce the negative effect of water stress. Mengel \& Arneke (1982) demonstrated that the importance of $\mathrm{K}^{+}$levels for maintaining proper water potential and turgor pressure. That role due to positive response of potassium in osmotic adjustment and regulation water potential in plant through stomata conductance, therefore potassium consider one of easy important strategically ways to face problems of water deficit and scarcity (Hassan et al., 2016). In general, the highest cotton yield were recorded for cotton plants irrigated every 12 or 15 days and received $48 \mathrm{~kg} \mathrm{~K}_{2} \mathrm{O} / \mathrm{fad}$. On the other hand, the plants watered every 21 days and fertilized with $12 \mathrm{~kg} \mathrm{~K}_{2} \mathrm{O} /$ fad yielded the lowest seed cotton yield.

\section{Earliness (\%), seed index, lint (\%) and fiber quality}

Data present in Table 4 show that potassium fertilization rates significantly affected earliness percentage and seed index, while lint percentage and fiber quality were not affected in both seasons. Increasing the rate of potassium fertilizer as soil application, was significantly decreased the earliness percentage in both seasons. This may be due to potassium had a promotive effect on vegetative growth (Table 3) led to delay the beginning of flowering. In this concern, Abd ElGayed et al. (2014) pointed out that NPK fertilizers produced the maximum days of seed cotton maturity. On the other hand, increasing potassium level was significantly increased seed index which may be due to added favorable potassium fertilization enhanced formation of carbohydrates, proteins, photosynthesis regulation, enzyme action, synthesis of nucleic acids, chlorophyll oxidative, photo-phosphorylation of solution Mengel \& Kirkby (1987).

As for the irrigation treatments, the results clearly show that irrigation intervals significantly affected earliness percentage and seed index, while lint percentage and fiber properties did not affect. Increasing irrigation intervals were significantly increased earliness percentage. Prolonging irrigation intervals to 21 days increased earliness (\%) by about $5.2 \%$ when compared with irrigation every 12 days. However, increasing irrigation intervals decreased seed index. Similar results are in harmony with those obtained by Hamoda et al. (2014) for cotton earliness.

Considering the interaction effect, the results indicate that earliness (\%), seed index, lint (\%) and fiber quality did not affect by the interaction between irrigation intervals and potassium fertilization. In general, cotton plants watered every 21 days and supplied with 12 days $\mathrm{kg} \mathrm{K}_{2} \mathrm{O} /$ fad produced the highest earliness percentage and lowest seed index. On other hand, the plants irrigated every 12 days and fertilized with $48 \mathrm{~kg} \mathrm{~K} \mathrm{O} /$ fad as soil application exhibited the lowest earliness percentage and heaviest seeds.

\section{Chemical contents in cotton leaves}

Data in Table 5 represent the effect of irrigation and potassium treatments and their interaction on some chemical contents, i. e., N, P, $\mathrm{K}$, chlorophyll a, chlorophyll $\mathrm{b}$ and carotenoids in cotton leaves. The data reveal that potassium fertilization had a positive effect on all chemical content in cotton leaves, except phosphorus content. Increasing potassium levels as soil application were significantly increased $\mathrm{N}$ and $\mathrm{K}$ content as well as chlorophyll a and chlorophyll $\mathrm{b}$ and carotenoids. In this concern, Rosolem et al. (2003) reported that root growth rate, length and surface had been associated with $\mathrm{K}$ acquisition efficiency of root system, consequently improved nutrient absorption. In addition, Pettigrew (2008) mentioned that potassium plays an important role in many physiological process (photosynthesis, assimilate transport, water relations and protein metabolism), therefore enhanced leaf pigments. Similar results were obtained by Aneela \& Ashraf (2003) and Abd El-Gayed (2009).

With regard to the main effect of irrigation treatments, the data show that, N, P and K as well as pigments content in cotton leaves were decreased steady with the irrigation levels. The highest means of these chemical contents $(3.69 \%, 0.33 \%, 3.37 \%$ and $3.20,2.88$ and $0.70 \mathrm{mg} / \mathrm{g}$, dw for $\mathrm{N}, \mathrm{P}, \mathrm{K}$ and chlorophyll a, chlorophyll b and carotenoids, respectively) were recorded and irrigation cotton plants every 12 days. This may be due to increasing amount of applied water increased solubility of nutrients, consequently increased its uptake. Increasing the nutrient uptake by plant leading to increasing plant canopy and hence increasing exposed area of leaves to sunlight which led to 
increasing chlorophyll content (Farrag et al., 2015). The results are in agreement with those obtained by Mazhar et al. (2006 a,b) and Azza et al. (2006) on Taxodium distichum.

As for the effect of the interaction between irrigation and potassium treatments on chemical content in cotton leaves, the results clearly show that all studied chemical contents in leaves, were not affected by the interaction between the two treatments. In general, the highest N, P and pigments were recorded for cotton plants watered every 12 days and fertilized with $48 \mathrm{~kg} \mathrm{~K}_{2} \mathrm{O} / \mathrm{fad}$ as soil application. Whereas, the lowest values for these chemical content were obtained for plants irrigated every 21 days and fertilized with $12 \mathrm{~kg}$ $\mathrm{K}_{2} \mathrm{O} / \mathrm{fad}$.

TABLE 4. Effect of irrigation intervals under potassium fertilization on earliness (\%), lint (\%), seed index, micronaire reading and pressely index of cotton plant.

\begin{tabular}{|c|c|c|c|c|c|c|c|c|c|c|c|}
\hline \multirow{2}{*}{$\begin{array}{l}\text { Irrigation } \\
\text { intervals (A) }\end{array}$} & \multirow{2}{*}{$\begin{array}{c}\text { Potassium } \\
\text { fertilization (B) }\end{array}$} & \multicolumn{2}{|c|}{ Earliness (\%) } & \multicolumn{2}{|c|}{ Seed index (g) } & \multicolumn{2}{|c|}{ Lint $(\%)$} & \multicolumn{2}{|c|}{$\begin{array}{l}\text { Micronaire } \\
\text { reading }\end{array}$} & \multicolumn{2}{|c|}{ Pressely index } \\
\hline & & 2016 & 2017 & 2016 & 2017 & 2016 & 2017 & 2016 & 2017 & 2016 & 2017 \\
\hline \multirow{5}{*}{$\begin{array}{l}\text { Every } 12 \\
\text { days }\end{array}$} & $12 \mathrm{~kg} \mathrm{~K}_{2} \mathrm{O} / \mathrm{fad}$ & 87.41 & 86.93 & 10.90 & 10.87 & 40.15 & 40.17 & 4.6 & 4.8 & 8.3 & 8.4 \\
\hline & $24 \mathrm{~kg} \mathrm{~K}_{2} \mathrm{O} / \mathrm{fad}$ & 86.92 & 86.48 & 10.95 & 10.92 & 40.11 & 40.13 & 4.7 & 4.5 & 8.7 & 8.3 \\
\hline & $36 \mathrm{~kg} \mathrm{~K}_{2} \mathrm{O} / \mathrm{fad}$ & 86.56 & 86.03 & 11.03 & 11.01 & 40.16 & 40.17 & 4.7 & 4.7 & 8.4 & 8.7 \\
\hline & $48 \mathrm{~kg} \mathrm{~K}_{2} \mathrm{O} / \mathrm{fad}$ & 86.05 & 85.54 & 11.12 & 11.08 & 40.14 & 40.16 & 4.8 & 4.7 & 8.7 & 8.4 \\
\hline & $5 \mathrm{~kg} \mathrm{~K}_{2} \mathrm{O} /$ fad (foliar) & 86.60 & 86.10 & 10.94 & 10.91 & 40.13 & 40.15 & 4.6 & 4.6 & 8.7 & 8.6 \\
\hline Mean & & 86.71 & 86.22 & 10.99 & 10.96 & 40.14 & 40.16 & 4.7 & 4.7 & 8.6 & 8.5 \\
\hline \multirow{5}{*}{$\begin{array}{l}\text { Every } 15 \\
\text { days }\end{array}$} & $12 \mathrm{~kg} \mathrm{~K}_{2} \mathrm{O} / \mathrm{fad}$ & 87.36 & 86.95 & 10.85 & 10.83 & 40.14 & 40.15 & 4.7 & 4.6 & 8.2 & 8.7 \\
\hline & $24 \mathrm{~kg} \mathrm{~K}_{2} \mathrm{O} / \mathrm{fad}$ & 85.25 & 84.03 & 10.89 & 10.87 & 40.13 & 40.14 & 4.5 & 4.7 & 8.5 & 8.3 \\
\hline & $36 \mathrm{~kg} \mathrm{~K}_{2} \mathrm{O} / \mathrm{fad}$ & 84.63 & 84.25 & 10.92 & 10.90 & 40.12 & 40.13 & 4.6 & 4.8 & 8.6 & 8.4 \\
\hline & $48 \mathrm{~kg} \mathrm{~K}_{2} \mathrm{O} / \mathrm{fad}$ & 84.15 & 83.86 & 11.12 & 11.09 & 40.13 & 40.15 & 4.8 & 4.7 & 8.7 & 8.4 \\
\hline & $5 \mathrm{~kg} \mathrm{~K}_{2} \mathrm{O} /$ fad (foliar) & 84.61 & 84.30 & 10.88 & 10.86 & 40.15 & 40.15 & 4.6 & 4.6 & 8.7 & 8.7 \\
\hline Mean & & 85.20 & 84.68 & 10.93 & 10.91 & 40.13 & 40.14 & 4.6 & 4.7 & 8.5 & 8.5 \\
\hline \multirow{5}{*}{$\begin{array}{l}\text { Every } 18 \\
\text { days }\end{array}$} & $12 \mathrm{~kg} \mathrm{~K}_{2} \mathrm{O} / \mathrm{fad}$ & 87.21 & 86.82 & 10.81 & 10.79 & 40.14 & 40.16 & 4.6 & 4.6 & 8.6 & 8.5 \\
\hline & $24 \mathrm{~kg} \mathrm{~K}_{2} \mathrm{O} / \mathrm{fad}$ & 84.76 & 84.52 & 10.82 & 10.80 & 40.14 & 40.15 & 4.8 & 4.6 & 8.7 & 8.4 \\
\hline & $36 \mathrm{~kg} \mathrm{~K}_{2} \mathrm{O} / \mathrm{fad}$ & 84.25 & 83.86 & 10.87 & 10.85 & 40.13 & 40.17 & 4.7 & 4.7 & 8.3 & 8.5 \\
\hline & $48 \mathrm{~kg} \mathrm{~K}_{2} \mathrm{O} / \mathrm{fad}$ & 83.71 & 83.22 & 11.08 & 11.07 & 40.11 & 40.13 & 4.7 & 4.8 & 8.3 & 8.6 \\
\hline & $5 \mathrm{~kg} \mathrm{~K}_{2} \mathrm{O} /$ fad (foliar) & 84.27 & 83.82 & 10.83 & 10.81 & 40.14 & 40.15 & 4.6 & 4.7 & 8.8 & 8.7 \\
\hline Mean & & 84.84 & 84.45 & 10.88 & 10.87 & 40.13 & 40.15 & 4.7 & 4.7 & 8.5 & 8.5 \\
\hline \multirow{5}{*}{$\begin{array}{l}\text { Every } 21 \\
\text { days }\end{array}$} & $12 \mathrm{~kg} \mathrm{~K}_{2} \mathrm{O} / \mathrm{fad}$ & 85.53 & 85.03 & 10.74 & 10.71 & 40.13 & 40.15 & 4.6 & 4.7 & 8.6 & 8.7 \\
\hline & $24 \mathrm{~kg} \mathrm{~K}_{2} \mathrm{O} / \mathrm{fad}$ & 82.15 & 81.67 & 10.79 & 10.76 & 40.13 & 40.14 & 4.8 & 4.7 & 8.6 & 8.7 \\
\hline & $36 \mathrm{~kg} \mathrm{~K}_{2} \mathrm{O} / \mathrm{fad}$ & 81.63 & 81.13 & 10.83 & 10.81 & 40.13 & 40.16 & 4.7 & 4.8 & 8.7 & 8.6 \\
\hline & $48 \mathrm{~kg} \mathrm{~K}_{2} \mathrm{O} / \mathrm{fad}$ & 81.16 & 80.66 & 10.92 & 10.89 & 40.11 & 40.15 & 4.6 & 4.8 & 8.5 & 8.6 \\
\hline & $5 \mathrm{~kg} \mathrm{~K}_{2} \mathrm{O} /$ fad (foliar) & 81.64 & 81.14 & 10.78 & 10.76 & 40.12 & 40.14 & 4.8 & 4.6 & 8.5 & 8.5 \\
\hline Mean & & 82.42 & 81.93 & 10.81 & 10.79 & 40.12 & 40.15 & 4.7 & 4.7 & 8.6 & 8.6 \\
\hline \multirow{5}{*}{$\begin{array}{l}\text { Mean of } \\
\text { potassium } \\
\text { fertilization } \\
\text { (B) }\end{array}$} & $12 \mathrm{~kg} \mathrm{~K}_{2} \mathrm{O} / \mathrm{fad}$ & 86.88 & 86.43 & 10.83 & 10.80 & 40.14 & 40.16 & 4.6 & 4.7 & 8.4 & 8.6 \\
\hline & $24 \mathrm{~kg} \mathrm{~K}_{2} \mathrm{O} / \mathrm{fad}$ & 84.77 & 84.18 & 10.86 & 10.84 & 40.13 & 40.14 & 4.7 & 4.6 & 8.6 & 8.4 \\
\hline & $36 \mathrm{~kg} \mathrm{~K}_{2} \mathrm{O} / \mathrm{fad}$ & 84.27 & 83.82 & 10.91 & 10.89 & 40.14 & 40.16 & 4.7 & 4.7 & 8.5 & 8.6 \\
\hline & $48 \mathrm{~kg} \mathrm{~K}_{2} \mathrm{O} / \mathrm{fad}$ & 83.77 & 83.32 & 11.06 & 11.03 & 40.12 & 40.15 & 4.7 & 4.8 & 8.6 & 8.5 \\
\hline & $5 \mathrm{~kg} \mathrm{~K}_{2} \mathrm{O} / \mathrm{fad}$ (foliar) & 84.28 & 83.84 & 10.86 & 10.84 & 40.14 & 40.15 & 4.7 & 4.6 & 8.7 & 8.6 \\
\hline \multicolumn{12}{|l|}{ L. S. D. at $5 \%$} \\
\hline & A & 0.08 & 0.07 & 0.03 & 0.02 & N.S & N.S. & N.S & N.S & N.S & N.S \\
\hline & & 0.09 & 0.09 & 0.02 & 0.04 & N.S & N.S & N.S & N.S & N.S & N.S \\
\hline & B & N.S & N.S & N.S & N.S & N.S & N.. & N.S & N.S & N.S & N.S \\
\hline & $\mathrm{AXB}$ & & & & & & & & & & \\
\hline
\end{tabular}


EFFECT OF REDUCED IRRIGATION AND POTASSIUM FERTILIZATION...

TABLE 5. Effect of irrigation intervals under potassium fertilization on some chemical content for 2017 season only.

\begin{tabular}{|c|c|c|c|c|c|c|c|}
\hline $\begin{array}{l}\text { Irrigation } \\
\text { intervals (A) }\end{array}$ & $\begin{array}{l}\text { Potassium fertilization } \\
\text { (B) }\end{array}$ & N (\%) & $\mathbf{P}(\%)$ & $\mathbf{K}(\%)$ & $\begin{array}{l}\text { Chlorophyll a } \\
(\mathrm{mg} / \mathrm{g}, \mathrm{dw})\end{array}$ & $\begin{array}{l}\text { Chlorophyll b } \\
\text { (mg/g, dw) }\end{array}$ & $\begin{array}{c}\text { Carotenoids } \\
(\mathrm{mg} / \mathrm{g}, \mathrm{dw})\end{array}$ \\
\hline \multirow{5}{*}{ Every 12 days } & $12 \mathrm{~kg} \mathrm{~K}_{2} \mathrm{O} / \mathrm{fad}$ & 3.61 & 0.33 & 3.33 & 3.16 & 2.84 & 0.65 \\
\hline & $24 \mathrm{~kg} \mathrm{~K}_{2} \mathrm{O} / \mathrm{fad}$ & 3.66 & 0.32 & 3.36 & 3.18 & 2.87 & 0.68 \\
\hline & $36 \mathrm{~kg} \mathrm{~K}_{2} \mathrm{O} / \mathrm{fad}$ & 3.73 & 0.33 & 3.38 & 3.21 & 2.90 & 0.72 \\
\hline & $48 \mathrm{~kg} \mathrm{~K}_{2} \mathrm{O} / \mathrm{fad}$ & 3.78 & 0.32 & 3.41 & 3.27 & 2.93 & 0.77 \\
\hline & $5 \mathrm{~kg} \mathrm{~K}_{2} \mathrm{O} /$ fad (foliar) & 3.67 & 0.33 & 3.37 & 3.19 & 2.87 & 0.69 \\
\hline Mean & & 3.69 & 0.33 & 3.37 & 3.20 & 2.88 & 0.70 \\
\hline \multirow{5}{*}{ Every 15 days } & $12 \mathrm{~kg} \mathrm{~K}_{2} \mathrm{O} / \mathrm{fad}$ & 3.59 & 0.30 & 3.20 & 3.12 & 2.80 & 0.62 \\
\hline & $24 \mathrm{~kg} \mathrm{~K}_{2} \mathrm{O} / \mathrm{fad}$ & 3.62 & 0.30 & 3.23 & 3.15 & 2.83 & 0.64 \\
\hline & $36 \mathrm{~kg} \mathrm{~K}_{2} \mathrm{O} / \mathrm{fad}$ & 3.66 & 0.29 & 3.27 & 3.18 & 2.86 & 0.66 \\
\hline & $48 \mathrm{~kg} \mathrm{~K}_{2} \mathrm{O} / \mathrm{fad}$ & 3.70 & 0.29 & 3.32 & 3.20 & 2.89 & 0.69 \\
\hline & $5 \mathrm{~kg} \mathrm{~K}_{2} \mathrm{O} /$ fad (foliar) & 3.61 & 0.30 & 3.24 & 3.16 & 2.83 & 0.64 \\
\hline Mean & & 3.64 & 0.30 & 3.25 & 3.16 & 2.84 & 0.65 \\
\hline \multirow{5}{*}{ Every 18 days } & $12 \mathrm{~kg} \mathrm{~K}_{2} \mathrm{O} / \mathrm{fad}$ & 3.55 & 0.27 & 3.12 & 3.09 & 2.78 & 0.60 \\
\hline & $24 \mathrm{~kg} \mathrm{~K}_{2} \mathrm{O} / \mathrm{fad}$ & 3.58 & 0.28 & 3.16 & 3.12 & 2.81 & 0.62 \\
\hline & $36 \mathrm{~kg} \mathrm{~K}_{2} \mathrm{O} / \mathrm{fad}$ & 3.62 & 0.27 & 3.19 & 3.16 & 2.84 & 0.64 \\
\hline & $48 \mathrm{~kg} \mathrm{~K}_{2} \mathrm{O} / \mathrm{fad}$ & 3.66 & 0.28 & 3.22 & 3.19 & 2.87 & 0.66 \\
\hline & $5 \mathrm{~kg} \mathrm{~K}_{2} \mathrm{O} /$ fad (foliar) & 3.58 & 0.27 & 3.15 & 3.12 & 2.82 & 0.63 \\
\hline Mean & & 3.60 & 0.27 & 3.17 & 3.14 & 2.82 & 0.63 \\
\hline \multirow{5}{*}{ Every 21 days } & $12 \mathrm{~kg} \mathrm{~K}_{2} \mathrm{O} / \mathrm{fad}$ & 3.51 & 0.25 & 3.05 & 3.05 & 2.75 & 0.58 \\
\hline & $24 \mathrm{~kg} \mathrm{~K}_{2} \mathrm{O} / \mathrm{fad}$ & 3.55 & 0.24 & 3.10 & 3.08 & 2.78 & 0.60 \\
\hline & $36 \mathrm{~kg} \mathrm{~K}_{2} \mathrm{O} / \mathrm{fad}$ & 3.58 & 0.25 & 3.14 & 3.11 & 2.82 & 0.62 \\
\hline & $48 \mathrm{~kg} \mathrm{~K}_{2} \mathrm{O} / \mathrm{fad}$ & 3.62 & 0.26 & 3.18 & 3.15 & 2.86 & 0.64 \\
\hline & $5 \mathrm{~kg} \mathrm{~K}_{2} \mathrm{O} /$ fad (foliar) & 3.54 & 0.26 & 3.11 & 3.07 & 2.78 & 0.62 \\
\hline Mean & & 3.56 & 0.25 & 3.12 & 3.09 & 2.80 & 0.61 \\
\hline \multirow{5}{*}{$\begin{array}{l}\text { Mean of potassium } \\
\text { fertilization (B) }\end{array}$} & $12 \mathrm{~kg} \mathrm{~K}_{2} \mathrm{O} / \mathrm{fad}$ & 3.57 & 0.29 & 3.18 & 3.11 & 2.79 & 0.61 \\
\hline & $24 \mathrm{~kg} \mathrm{~K}_{2} \mathrm{O} / \mathrm{fad}$ & 3.60 & 0.29 & 3.21 & 3.13 & 2.82 & 0.64 \\
\hline & $36 \mathrm{~kg} \mathrm{~K}_{2} \mathrm{O} / \mathrm{fad}$ & 3.65 & 0.29 & 3.25 & 3.17 & 2.86 & 0.66 \\
\hline & $48 \mathrm{~kg} \mathrm{~K}_{2} \mathrm{O} / \mathrm{fad}$ & 3.69 & 0.29 & 3.28 & 3.20 & 2.89 & 0.69 \\
\hline & $5 \mathrm{~kg} \mathrm{~K}_{2} \mathrm{O} / \mathrm{fad}$ (foliar) & 3.60 & 0.29 & 3.22 & 3.14 & 2.83 & 0.65 \\
\hline \multicolumn{8}{|l|}{ L. S. D. at $5 \%$} \\
\hline A & & 0.02 & 0.02 & 0.04 & 0.01 & 0.01 & 0.02 \\
\hline $\mathrm{B}$ & & 0.02 & N. S. & 0.03 & 0.02 & 0.02 & 0.01 \\
\hline $\mathrm{A} \times \mathrm{B}$ & & N.S & N.S & N.S & N.S & N.S & N.S \\
\hline
\end{tabular}

Irrigation water applied (IWA, $\mathrm{m}^{3} \mathrm{fad}^{-1}$ )

Data in Table 6 represent the amount of irrigation water applied under the four irrigation treatments. The summation of the amount of planting, live and third irrigation were 1763, 1766, 1767 and $1772 \mathrm{~m}^{3}$ fad $^{-1}$ for $12,15,18$ and 21 days interval treatments, respectively in the first season. The corresponding values for the second season were 1747, 1750, 1753 and $1776 \mathrm{~m}^{3} \mathrm{fad}^{-1}$. The total water applied was increased as the intervals between irrigation decreased. The highest values of total applied water $\left(5035\right.$ and $5012 \mathrm{~m}^{3} \mathrm{fad}^{-1}$ in the two seasons, respectively) were recorded under irrigated cotton plants every 12 days. Whereas, the lowest total applied water (3526 and $3531 \mathrm{~m}^{3} \mathrm{fad}^{-1}$ in both seasons, respectively) were due to irrigated every 21 days. The data reveal that irrigated cotton plants every 15 days could save about 9.3 and $9.4 \%$ of applied water compared with $100 \%$ from irrigation requirements (watered every 12 days) with reduction in seed cotton yield only by about 3, 0 and $4.7 \%$ in both seasons, respectively. Furthermore, it could be saved 9.3 and $9.4 \%$ of applied water when fertilized cotton plant with $48 \mathrm{~kg} \mathrm{~K}_{2} \mathrm{O} / \mathrm{fad}$ as soil application without any statistical decreasing in seed cotton yield (Table 3 ). 
TABLE 6. Number of irrigation and applied water $\left(\mathrm{m}^{3} \mathrm{fad}^{-1}\right)$ for each irrigation under different irrigation treatments during 2016 and 2017 seasons.

\begin{tabular}{|c|c|c|c|c|c|c|c|c|}
\hline \multirow{2}{*}{$\begin{array}{l}\text { Treatments } \\
\text { Irrigation event }\end{array}$} & \multicolumn{2}{|c|}{ Every 12 days } & \multicolumn{2}{|c|}{ Every 15 days } & \multicolumn{2}{|c|}{ Every 18 days } & \multicolumn{2}{|c|}{ Every 21 days } \\
\hline & 2016 & 2017 & 2016 & 2017 & 2016 & 2017 & 2016 & 2017 \\
\hline Planting irrigation & 685 & 670 & 684 & 673 & 679 & 670 & 672 & 668 \\
\hline Live irrigation & 521 & 525 & 523 & 527 & 526 & 529 & 531 & 536 \\
\hline Third irrigation & 557 & 552 & 559 & 550 & 562 & 554 & 569 & 572 \\
\hline Fourth irrigation & 577 & 571 & 573 & 573 & 570 & 577 & 580 & 581 \\
\hline Fifth irrigation & 596 & 590 & 592 & 592 & 591 & 598 & 596 & 601 \\
\hline Sixth irrigation & 575 & 571 & 578 & 574 & 582 & 576 & 578 & 573 \\
\hline Seventh irrigation & 564 & 570 & 566 & 568 & 568 & 571 & --- & --- \\
\hline Eight irrigation & 530 & 527 & 532 & 525 & --- & --- & --- & --- \\
\hline Ninth irrigation & 430 & 436 & ---- & ---- & --- & --- & --- & --- \\
\hline Total irrigation & 5035 & 5012 & 4607 & 4582 & 4078 & 4075 & 3526 & 3531 \\
\hline
\end{tabular}

\section{Water relations}

The data in Table 6 represent as the seasonal consumptive use $\left(\mathrm{CU}, \mathrm{m}^{3} \mathrm{fad}^{-1}\right)$, water utilization efficiency (WUE, $\mathrm{kg} \mathrm{m}^{-3}$ ) and water use efficiency (WUE, $\mathrm{kg} \mathrm{m}^{-3}$ ) as affected by irrigation and potassium treatments and their interaction.

\section{Water consumptive use}

The results indicate that the full irrigation (every 12 days) gave the highest amount of the seasonal consumptive use (3892 and $3859 \mathrm{~m}^{3} \mathrm{fad}^{-1}$ in both seasons, respectively). On the other hand, irrigated cotton plants every 21 days exhibited the lowest water consumptive use $\left(3071\right.$ and $3021 \mathrm{~m}^{3}$ $\mathrm{fad}^{-1}$ in both seasons, respectively. The superiority of full irrigation treatment to high seasonal water consumptive use is due to the abundance of soil moisture in soil and the plants tend to grow without stress in the last stage of growth, hence use more water (Ewis et al., 2015). In addition Ayotamuno et al. (2007) and Abd El-Latif et al. (2016) reported that the increment in water consumption by plants depended on availability of soil moisture in the root zone and plant growth stage. These results are in line with those obtained by Moussa \& Abdel-Maksoud (2004). As potassium treatments, the data reveal that water consumptive use values were positively responded to potassium levels. Fertilized cotton plants with $48 \mathrm{~kg} \mathrm{~K}_{2} \mathrm{O} /$ fad gave higher $\mathrm{CU}$ values than other treatments. These results may be due to the plants supplied with its recommended rate of potassium exerted higher root and shoot growth, consequently consumed more water. Similar results were obtained by Farrag et al. (2015). Regarding the interaction effect, the results show that the highest values of $\mathrm{CU}$ were obtained in plants grown under full irrigation treatment and supplied with $48 \mathrm{~kg}$ $\mathrm{K}_{2} \mathrm{O}$ /fad, while the plants watered every 21 days and received $12 \mathrm{~kg} \mathrm{~K}_{2} \mathrm{O} /$ fad recorded the lowest one.

Water utilization efficiency (WUtE) and water use efficiency (WUE)

The efficiency water utilization is an important limiting factor to crop production. Results reveal that values of WUtE and WUE were affected by irrigation treatments and potassium levels. The data in Table 7 show that the average of water utilization efficiency were $0.34,0.36,0.41$ and $0.45 \mathrm{~kg}$ seed cotton for each cubic meter of water due to 12,15 , 18 and 21 days intervals in the first season. The corresponding values for water use efficiency were $0.45,0.49,0.51$ and $0.51 \mathrm{~kg} \mathrm{~m}^{-3}$. Similar trends were obtained for the second season. It is obvious to notice that increasing the amount of irrigation water caused a significant decreasing in water utilization efficiency and water use efficiency which is mostly due to the increase in water loss by leaching. The results, also show that WUtE and WUE were positively responded to increasing potassium level up to $48 \mathrm{~kg} \mathrm{~K}_{2} \mathrm{O} / \mathrm{fad}$ as soil application, which mainly due to the effect of potassium on seed cotton yield. Therefore, using 100\% potassium mineral fertilizer was the most efficient potassium level under all irrigation treatments. As for the interaction between the two studied treatments, the results clearly show that WUtE and WUE did not respond to the interaction between water and potassium treatments. The highest values for these two water relations were obtained under irrigated cotton plants every 21 days and fertilized with $48 \mathrm{~kg} \mathrm{~K}_{2} \mathrm{O} /$ fad, while the plants watered every 12 days and received $12 \mathrm{~kg} \mathrm{~K}_{2} \mathrm{O} /$ fad exhibited the lowest ones. 
TABLE 7. Applied water (IWA, $\left.\mathrm{m}^{3} \mathrm{fad}^{-1}\right)$, water consumptive use $\left(\mathrm{CU}, \mathrm{m}^{3} \mathrm{fad}^{-1}\right)$, water used efficiency (WUE, $\mathrm{kg}$ $\mathrm{m}^{-3}$ ) and water utilization efficiency (WUtE, $\mathrm{kg} \mathrm{m}^{-3}$ ) as affected by irrigation intervals and potassium treatments.

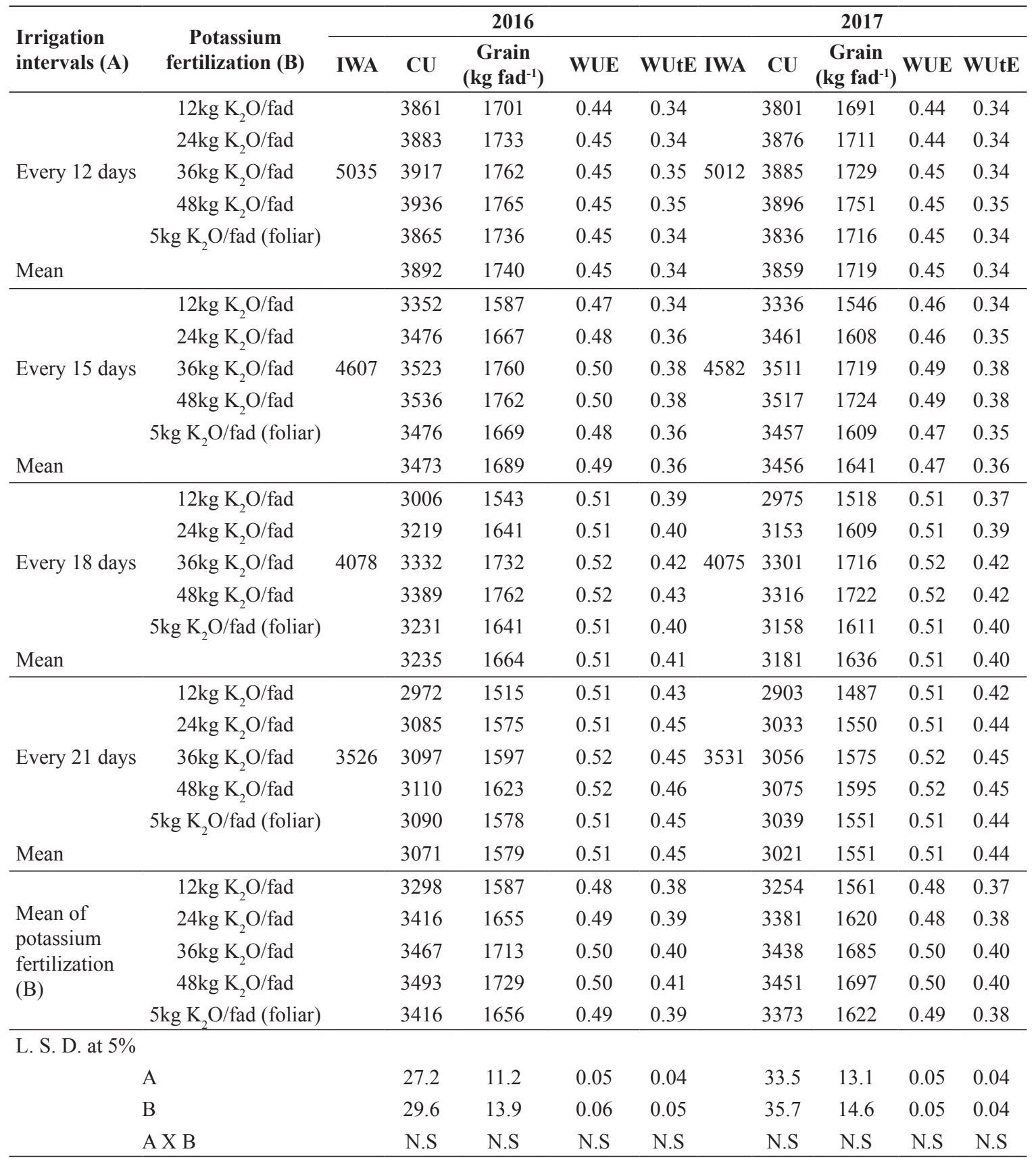

\section{Conclusion}

It could be conclude to irrigated cotton plant every 15 days and added $48 \mathrm{~kg} \mathrm{~K}_{2} \mathrm{O} /$ fad to attain the highest seed cotton yield, which equal to those produced under full irrigation (every 12 days) Beni Suef irrigation conditions. This means that saving about $9 \%$ from water required for cotton plants under.

\section{References}

Abd El-Aal, H.A., Ziadah, K.A., Darwish, A.A. and El-Shazly, W.M.O. (2000) Proper hill spacing and optimum NPK rate for cotton Giza 89. Alex. Sci. Exch. 21(3), 197-210.

Abd El-Gayed, S.Sh. (2009) Physiological effect of potassium and boron fertilization under two planting 
dates on productivity of egyptian cotton plant. $P h$. D. Thesis, Fac. Agric., Benha Univ., Egypt.

Abd El-Gayed, S.Sh. and Awadalla, H.A. (2014) Response of cotton hypryd [(Giza 83 x (Giza $75 \times 5844)] \times$ Giza 80] to different sources and application methods of potassium fertilizers. Egypt. J. Agric. Res. 92(1), 181-195.

Abd El-Gayed, S.Sh., Wassel, O.M.M. and Ghourab, M.H.H. (2014) Response of Cotton Giza 80 to nonradical nutrition during flowering stage of growth. Egypt. J. Agric. Res. 92(1), 169-180.

Abd El-Latif, K.M., Mohmoud, M.A., Ewis, M.M. and El-Akram, M.F.I. (2016) Effect of skipping the last irrigation on the productivity and some water relations of four maize hybrids under Middle Egypt conditions. $1^{\text {st }}$ International Conference on Applied Microbiology, March 1-3, Giza, Egypt, pp. 163178.

Abd El-Shafy, N.A., Menshawi, M.E. and Girgis, E.A. (2001) Effect of some macro and micro-nutrients fertilization on cotton yield. Menofiya J. Agric. Res. 26(3), 673-687.

Akbari, N.D. (2011) Effect of water on yield, water use efficiency and function of cotton production in the Mazandaran province. Journal of Agricultural Science and Stable Pproduction, 21(1), 111-103.

Akhtar, M.E., Sardar, A., Ashraf, M., Akhtar, M. and Khan, M.Z. (2003) Effect of potash application on seed cotton yield and yield components of selected cotton varieties-I. Asian J. Plant Sci. 2(8), 602-604.

Aneela, S.M. and Ashraf, A.M.E. (2003) Effect of potash on boll characteristics and seed cotton yield in newly developed highly resistant cotton varieties. Pak. J. Bio. Sci. 6(9), 813-815.

Arnon, D.I. (1949) Copper enzymes in isolated chloroplasts, polyphenol oxidase in Beta vulgaris. PI. Physiol. 24, 1-15.

Ashry, M.R.K., Farag, F.R.M., Abdou, S.M.M. and ElAkram, M.F.I. (2012) Rationalization of irrigation water use for faba bean (Vicia faba L.). Fayoum J. Agric. Res. and Dev. 26(1), 26-37.

Ayotamuno, J.M., Zuofa, K., Sunday, O.A. and Kogbara, B.R. (2007) Response of maize and cucumber intercrop to soil moisture control through irrigation and mulching during the dry season in Nigeria. African Journal of Biotechnology, 6(5), 509-515.

Azza, A.M.M., Zaghloul, S.M. and Yassen, A.A. (2006) Impact of boron fertilizer on growth and chemical constituents of Taxodium distichum grown under water regime. World Journal of Agricultural Sciences, 2(4), 412-420.

Brag, H. (1972) The influence of potassium on the transpiration rate and stomata opening in Triticum aestivum and Pisum sativum. Plant Physiol. 26, 250-257.

Burke, J.J. and Omahony, J. (2001) Protective role in acquired term tolerance of developmentally regulated heat shock proteins in cotton seeds. Journal of Cotton Science, 2, 147-183.

Chapman, H.D. and Pratt, P.F. (1961) "Methods of Analysis of Soils, Plants, and Water". Univ. Calf., Depart. Agric. Sci. USA, p.320.

Chen, J. and Gabelman, W.H. (2000) Morphological and physiological characteristics of tomato root associated with potassium-acquisition efficiency. Scientia Horticulturae, Amsterdam, 83, 213-225.

Cope Jr., J.T. (1981) Effect of 50 years of fertilization with phosphorous and potassium on soil test levels and yields at six locations. Soil Sci. Soc. Am. J. 45, 342-347.

Dagdelen, N., Yilmaz, E., Sezgin, F. and Gorbuz, T. (2006) Water yield relation and water use efficiency of cotton and season crop corn in Western Turkey. Agric. Water Manage. 82(1-2), 93-85.

Davis, M.R., Coker, G., Parfit, R.L., Simcock, R., Clinton, P.W., Garrett, L.G. and Watt, M.S. (2007) Relationships between soil and foliar nutrients in young densely planted mini-plots of pinus radiate and cupressus lusitanica. Forest Ecol. Manage. 240, 122-130.

Ewis, M.M., Abd El-Latif, K.M. and Badawi, M.I. (2015) Effect of irrigation interval and phosphorus fertilization rate on faba (Vicia faba L.) yield, yield components and some crop-water relationships. $J$. Soil Sci. Agric. Eng., Mansoura Univ. 6, 705-718.

Farrag, D.K.H., Darwes, R.K.H. and Moursi, E.A. (2015) The combined effect between irrigation and 
K-fertilizer forms on squash productivity in the north Nile delta region. Bull. Fac. Agric., Cairo Univ. 66, 180-195.

FAO (2003) Unlocking the Water Potential of Agriculture. FAO. Corporate Document Repository. 260pp.

Fathi, A., Sohrabi, B. and Born Small, D. (2011) Effects of different irrigation regimes and nitrogen fertilizer on yield and yield components of cotton irrigation methods and groove. Electronic Journal of Crop Production, 4(1), 74-61.

Gebaly, S.G. (2012) Physiological effects of potassium forms and methods of application on cotton variety Giza 80. Egypt. J. Agric. Res. 90(4), 1633-1647.

Geerts, S. and Raes, D. (2009) Deficit irrigation as an onfarm strategy to maximize crop water productivity in dry areas. Agric. Water Manage, 96(9), 1275-1284.

Ghourab, M.H.H., Wassel, O.M.M. and Raya, N.A. (2000) Effect of (Pottasin-P) ${ }^{\mathrm{Tm}}$ under two levels of nitrogen fertilizer on productivity of Giza 77 cotton. Egypt, J. Agric. Res. 78(2), 781-793.

Hafiz, Y.A. and Ewis, M.M. (2015) Effect of irrigation regime and potassium fertilization rates on growth, yield, oil composition and some water relations of fennel plant (Foeniculum vulgare Mill) under Middle Egypt conditions. Bull. Fac. Agric., Cairo Univ. 66, 142-155.

Hamoda, S.A.F., Ibrahim, M.A.A. and Emara, M.A.A. (2014) Effect of irrigation intervals and NPK fertilizers on growth, yield and quality for the new cotton hybrid [Giza 83 x (Giza75 x 5844)] x Giza 80. Egypt, J. Agric. Res. 92(1), 111-123.

Hassan, S.F., Ahmed, S.A. and Mohammed, L.I. (2016) Response of cotton to potassium levels under water regime. International J. Applied Agric. Sci. 2(4), 56-63.

Imam, T. (2004) "Agriculture Grain", Published Shiraz University, pp. 176.

Israelsen, O. and Hansen, V. (1962) "Irrigation, Principles and Practices". John Wiley and Sons, Inc. Pub. New York, USA.

Kassem, M.M.A. and Ahmed, F.A.M. (2005) Effect of potassium source and level on cotton productivity and soil chemical properties. Assiut J. Agric. Sci. 36(3), 77-90.

Khalifa, E.M.A., Deshish, E.D.E., Hamoda, S.A.F. and Shalaby, K.H.A. (2014) Effect of sprinkler irrigation system under differant pressures and planting patterns on growth and productivity of cotton plant. Egypt. J. Agric. Res. 92(1), 139-152.

Klute, A. (1986) "Methods of Analysis", $2^{\text {nd }}$ ed. Part 1: Physical and Mineralogical Methods. American Society of Agronomy, Mudision, Wisconsin, USA.

Mazhar, A.A. and Zaghloul, S.M. (2006 a) Increasing water deficiency tolerance of Melia azedarach seedlings through application of iron world. J. Agric. Sci. 2, 346-351.

Mazhar, A.A., Zaghloul, S.M. and Yassen, A.A. (2006 b) Impact of boron fertilizer on growth and chemical constituents of Taxodium distichum grown under water regime. World J. Agric. Sci. 2(4), 412-420.

Mengel, K. and Kirkby, E.A. (1987) "Principles of Plant Nutrition". International Potash Institute. CH, 3048 Wohblan Fen-bern, Switzerland.

Mengel, K. and Arneke, W.W. (1982) Effect of potassium on the water potential,the pressure potential, the osmotic potential and cell elongation in leaves of Phaseolus vulgaris. Physiol. Plants, 54, 402-408.

Michael, A.M. (1978) "Irrigation Theory and Practice". Vikas Publishing House PVT LTD New Delhi, India.

Moussa, A.M. and Abd El-Maksoud, H.H. (2004) Effect of soil moisture regime on yield and its components and water use efficiency for some wheat cultivars. Annals Agric. Sci., Ain Shams Univ. 49(2), 982-986.

Naseri, P. (1994) "Cotton", 2 $2^{\text {nd }}$ ed. Published Quds Razavi.

Onder, D., Akiscan, Y., Onder, S. and Mert, M. (2009) Effect of different irrigation water level on cotton yield and yield components. African J. Biotech. 8(8), 1536-1544.

Ouda, S.A., Abou Elenin, R. and Shreif, M.A. (2010) Simulating the effect of deficit irrigation on Egyption clover yield and water productivity. $14^{\text {th }}$ International Water Technology Coference, Cairo, Egypt, pp. 319-329. 
Page, A.L., Miller, R.H. and Keeny, D.R. (1982) "Methods of Soil Analysis", 2 2nd ed. Part 2: Chemical and Microbiological Properties. American Society of Agronomy, Madisons, Wisconsin, USA.

Pettigrew, W.T. (2008) Potassium influences on yield and quality production for maize, wheat, soybean and cotton. Physiologia Plantarum, 131, 670-781.

Reddy, K.R., Hodges, H.F. and Varco, J. (2000) Potassium nutrition of cotton. Bulletin 1094, Mississippi Agricultural and Forestry Experiment Station, Mississippi.

Rolbelen, G. (1957) Untersuchungen and Stroh Lenin Duzieten Blatt Arbumutonten Von Arbidopois Thaliana (L.). Verbungsie (Germany)..

Rosolem, C.A., Silva, R.H. and Esteves, J.A.F. (2003) Potassium supply to cotton roots as affected by potassium fertilization and liming. Pesq. Agropec. Bras. 38, 635-641.

Sawar, M., Jilani, G., Rafique, E., Akhtar, M.E. and Chaudhry, A.N. (2012) Impact of integrated nutrient management on yield and nutrient uptake by maize under rain-fad conditions. Pak. J. Nutr. 11, 27-33.

Siskani, A., Seghatoleslami, M. and Moosavi, G. (2015) Effect of deficit irrigation and nanofertilizers on yield and some morphological traits of cotton. Biological Forum - An International Journal, 7(1), 1710-1715.

Snedecor, G.W. and Cochran, W.G (1980) One-way classification Analysis of Variance. In: "Statisitical Methods", $8^{\text {th }}$ ed. Chapter 12, pp. 217-236. Iowa State University Press. Ames. Iowa, USA.

Tisdale, S.L., Nelson, W.L., Beaton, J.D. and Havlin, J.L. (1997) "Soil Fertility and Fertilizers". Macmillan Publ. Co., New York.

Vites, F.G. (1965) Increasing water use efficiency by soil management in plant environment and efficient water use. J. Amer. Soc. Agron. 26, 537-546.

Xiong, L. and. Zhu, J.K. (2002) Molecular and genetic aspects of plant responses to osmotic stress. Plant, Cell and Environment, 25, 131-139.

Zhao, T.J., Sun, S., Liu, Y., Liu, J.M., Liu, Q., Yan, Y.B. and Zhou, H.M. (2006) Regulating the drought responsive element (DRE)-mediated signaling pathway by synergic functions of trans-active and trans inactive DRE binding factors in Brassica napus. J. Biol. Chem. 281, 10752-10759.

(Received 15/10/2018; accepted 18/12/2018)

\section{تأثير تقليل مياة الري والتسميد البوتاسي على محصول القطن جيزة 95 كما ونوعا

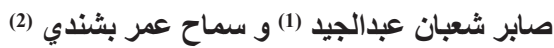

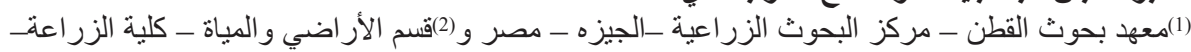 جامعة المنيا - المنيا - مصر . مركر.}

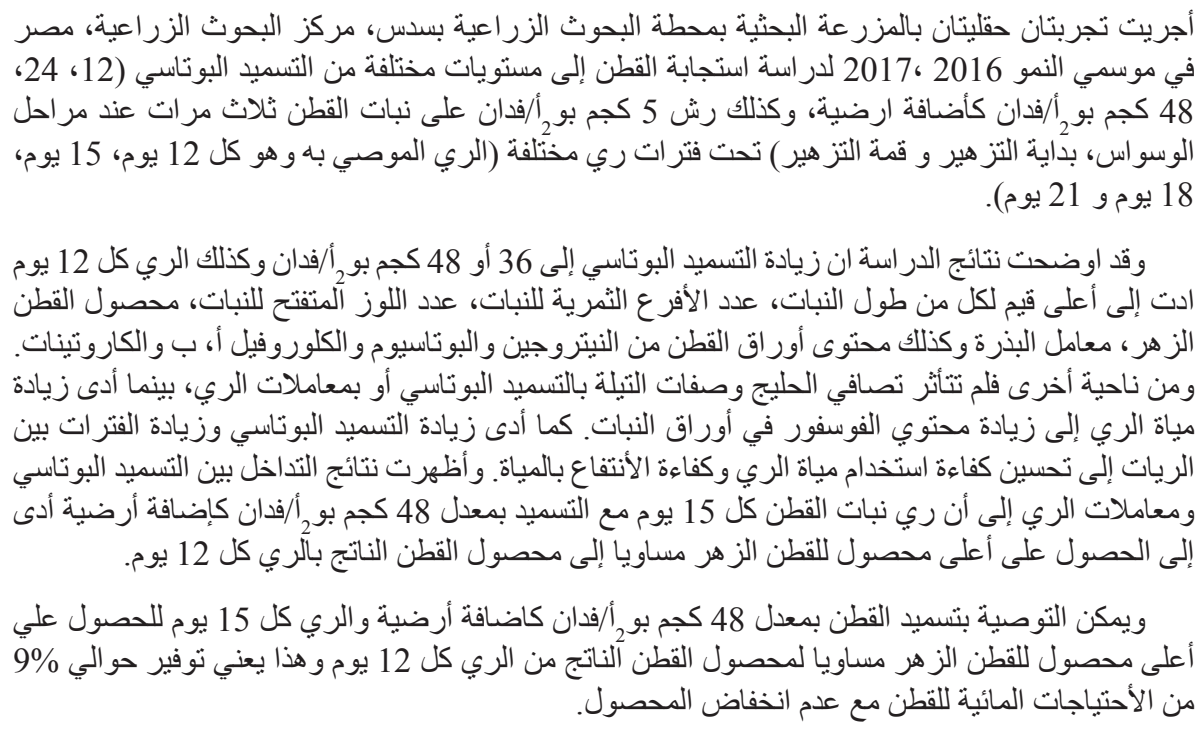

Egypt. J. Agron. Special Issue (2018) 